Original scientific paper

Received: 9 May 2021

Accepted: 15 September 2021

Vesna Kostović-Vranješ, PhD, Associate Professor

Faculty of Humanities and Social Sciences, University of Split

kostovic@ffst.hr

https://orcid.org/0000-0002-0161-9484

Mila Bulić, PhD, post-doctoral researcher

Faculty of Humanities and Social Sciences, University of Split mbulic@ffst.hr

https://orcid.org/0000-0002-8090-897X

Viktorija Periša, M. A. in Prim. Educ.

Vodice Primary School

\title{
ATTITUDES OF TEACHER EDUCATION STUDENTS AND CLASS TEACHERS TO DISTANCE EDUCATION
}

\begin{abstract}
The educational system of the Republic of Croatia saw the transition from classroom to distance education starting on March 13, 2020 due to the pandemic of the new, infectious coronavirus COVID-19. The pandemic caused a sudden transition to distance education and a number of difficulties in the implementation of online education, therefore a study was conducted to determine the attitudes of students, who are future class teachers, and practitioner-teachers to distance education in which they participated. The results of the research show significant differences in the perception of the transition from classroom to distance education, revealing it was more difficult for practitioner-teachers to organize and implement online education. The research determined attitudes to distance education and attitudes to television-based education. The obtained research results can be used to improve distance education, which will be carried out as needed, alternating with classroom teaching.
\end{abstract}

Keywords: e-learning, information and communication technology, television-based education, distance education, Science and Society classes 


\section{INTRODUCTION}

We often say that modern learners are members of the always online generation, who wants and expects the inclusion of information and communication technologies (hereinafter ICT) in education (Bulić and Novoselić, 2016). This obliges teachers to enhance their competences, including digital competence, because modern teaching leaves almost no place for the classes organized without the use of ICT. A digitally competent teacher should be able to act in a digital environment, be information literate (Nadrljanski, 2006, pp. 262-263), and prepared for lifelong learning. Since the Internet is today's main medium for transmission of information, a digitally competent teacher obtains the information needed to improve teaching through this medium. To help teachers assess which digital competences they need, the European Digital Competence Framework for Educators was developed in 2017. Basic competences are divided into six areas, which cover different aspects of professional activities: professional engagement, digital resources, teaching and learning, assessment, empowering learners, and facilitating learners' digital competence (CARNet, 2020). With the development of digitalization, all textbooks of Science and Society became digitalized, and the digital version is used in class by teachers and learners who can access e-content from home as well. That is why today, more than ever, lifelong learning and teachers' professional development are necessary. Therefore, it is essential to develop a basic digital competence in primary school teachers for the application of ICT for educational purposes during the initial teacher education.

Fully online classes can be extremely helpful in cases of learner illness or other excused absences when they cannot attend classes in the classroom. The health epidemiological situation that hit the world in the spring of 2020 forced most countries to switch to online and distance education in a very short time. The application of distance education implies the quality design of teaching content uploaded on e-platforms and the design of various and creative activities that will be stimulating for doing the assigned tasks. During the learning process, it is extremely important to regularly monitor learner activities, provide feedback on their work and homework, suggest activities for further progress and assess the achievement of the necessary learning outcomes.

\section{NATURAL SCIENCES AREA}

The National Curriculum Framework (NOK, 2010) defined the area of natural sciences as a whole based on the knowledge of natural sciences: biology, chemistry, physics, geophysics, and geology. The main goal of learning and teaching natural sciences is to develop science literacy, which means that learners use scientific concepts, methods, and procedures to solve problems and make decisions in everyday life as well as to respond to new challenges through 
lifelong learning. Observing the entire vertical of the educational system, it can be seen that the basics of scientific competence rely on the programs of the subject Science and Society in the first and second educational cycles and continue through the subjects Science and Geography in grades 5 and 6 (subject teaching), and subjects Biology, Chemistry, Physics, and Geography starting from grade 7. Natural sciences are important for the progress of any society, and it is necessary to make a special effort to develop science literacy of learners from an early age, which indicates the significance of Science and Society classes.

The school subject Science and Society, as an integral part of the area of natural sciences, aims to encourage and complement the knowledge about the characteristics, structures, function, diversity, distribution, interconnectedness, and variability of the living world. Science and Society is based on interdisciplinarity, connecting and uniting scientific knowledge of natural sciences, social sciences, humanities, technical and information sciences (Curriculum of the Subject Science and Society for Elementary Schools, 2019). The educational goals of Science and Society are achieved through four key interrelated concepts: Organization of the world around us, Changes and relationships, Energy, and The individual and society. These concepts are related to defined cross-curricular topics as well as other subjects of the first educational cycle. Each of the concepts relies on a research approach based on observation, reasoning, analysis, synthesis, and development of creativity and critical thinking (Curriculum of the Subject Science and Society for Elementary Schools, 2019). To achieve learning outcomes and the overall development of learners placed at the center of the educational process, the task of teachers is to organize classes that include different sources of knowledge, tools, aids, methods, techniques, and teaching strategies. It is the application of different teaching strategies that influences the development of learners' interest in teaching and increases the motivation to learn the content of the subject in question (Boras, 2009).

\section{ICT AND DISTANCE EDUCATION}

The application of ICT is increasingly affecting all life areas, including education. In addition to encouraging the acquisition of skills, ICT also serves for lifelong learning, opening daily new opportunities and perspectives in education (Hutinski and Aurer, 2009). According to Kostović-Vranješ (2015, p. 67). "Information and communication technologies include various technological tools and resources that are used for communication as well as for creating, storing and managing information, making it one of the basic building blocks of modern education". There are many possibilities of applying ICT in teaching, and in order to enrich and modernize their classes, to make them more interesting and to activate learners, teachers can use various technologies and digital tools: multimedia, communication and collaboration tools, digital textbooks, 
educational platforms, learning management systems, digital quizzes, social networks, video conferencing, mobile learning etc. When choosing technologies, the teacher should keep in mind the age of the learners and the specifics of the teaching content being covered.

The application of ICT enables diversity in the delivery of teaching content and communication among participants in the educational process. The use of digital content helps learners achieve learning outcomes in a way adapted to them (Bulić et al., 2017). As a tool that allows rapid exchange of information, images, text, sound, videos, etc., the Internet plays a major role in the application of ICT nowadays. When implementing ICT, we should bear in mind that the implementation is not an end in itself, but requires critical thinking about the reasons for implementation, learning outcomes as well as didactic design in order to improve teaching (Pejić Papak and Grubišić Krmpotić, 2016). Cross-curricular topic The use of ICT is covered in all subjects and indicates that learning and teaching with the help of computers and other digital devices encourage the development of knowledge, skills and attitudes related to the use of ICT. Learners use ICT purposefully and responsibly, research, communicate, collaborate, and create in the digital environment (Curriculum of the Crosscurricular Topic the Use of Information and Communication Technology for Elementary and Secondary Schools, 2019). Additionally, the use of ICT enhances the learners' self-responsibility, especially if they hand in their homework online and have exact deadlines (Bulić and Kostović-Vranješ, 2019).

Tinio (2003) emphasizes that ICT technologies and tools that combine text, sound, and images can be used to provide challenging and authentic content that will engage learners in the learning process. The implementation of ICT in learning accelerates access to information, achieves interactivity, and provides the possibility of independent and personalized learning (Ćukušić and Jadrić, 2012). To facilitate the understanding of different forms of instruction with regard to the implementation of ICT with emphasis on the percentage of online content delivery, we present a table (Table 1) designed according to Allen and Seaman (2013). With regard to the implementation of ICT and the delivery of teaching content via the Internet, the authors divide instruction into: traditional instruction, web-assisted instruction, hybrid instruction, and online instruction. Traditional instruction implies classroom teaching, focused on the teacher and teaching content. In this form of instruction, the learner is mostly passive and has the role of a passive listener. Although online technologies are not used in traditional instruction, teachers can use technology without the use of the Internet, computer, and projector. 
Table 1. Forms of instruction with regard to the implementation of ICT and the delivery of teaching content online (according to Allen and Seaman, 2013).

\begin{tabular}{|c|c|c|}
\hline $\begin{array}{l}\text { Percentage of } \\
\text { online content } \\
\text { delivery }\end{array}$ & $\begin{array}{l}\text { Forms of } \\
\text { instruction }\end{array}$ & Description \\
\hline $0 \%$ & $\begin{array}{l}\text { traditional (face-to- } \\
\text { face) instruction }\end{array}$ & $\begin{array}{l}\text { Classes take place in classroom, online } \\
\text { technologies are not used. }\end{array}$ \\
\hline $1 \%$ to $29 \%$ & $\begin{array}{l}\text { web-assisted } \\
\text { instruction }\end{array}$ & $\begin{array}{l}\text { Technology is used to improve traditional } \\
\text { teaching. The teacher posts the learning } \\
\text { content on the course's web pages, uses } \\
\text { the Web content in classes. The teacher } \\
\text { uses e-mail to communicate with the } \\
\text { learners. }\end{array}$ \\
\hline $30 \%$ to $79 \%$ & hybrid instruction & $\begin{array}{l}\text { A combination of classroom teaching and } \\
\text { online teaching. A large proportion of } \\
\text { teaching content is delivered online. LMS } \\
\text { (Learning Management Systems) are } \\
\text { often used for the delivery. }\end{array}$ \\
\hline $80 \%$ and more & online instruction & $\begin{array}{l}\text { Teaching content is mostly delivered } \\
\text { online (usually using an LMS). There is } \\
\text { usually no face-to-face teaching. }\end{array}$ \\
\hline
\end{tabular}

Teachers can use a computer to prepare lessons, for example they can make a lesson plan in Word, and a presentation in PowerPoint. The presentation will be shown using a computer and a projector. This form of instruction is the most common, but it is not purposeful as the learners do not acquire the knowledge through their own activity. A departure from traditional instruction is seen in web-assisted instruction. The teacher has at disposal countless Internet resources, tools, and technologies that can be used directly during classes, but also after class for the purpose of communication, cooperation, activation, and involvement of learners in the teaching process. Hybrid instruction combines traditional and online teaching with the help of ICT. Learners learn both at school and at home, and this form of teaching encourages their activity and independent work, while the availability of teaching content facilitates learning and planning. In online instruction, learning and teaching generally take place fully online. Here, learning management systems are often used for communication, delivery of teaching content, cooperation, evaluation etc. The success of this form of instruction mostly depends on learners, their motivation, responsibilities, and activities.

Distance education is a form of education which started in $19^{\text {th }}$ century (Zenović and Bagarić, 2014). In the beginning, it was focused on non-traditional 
students; soldiers, full-time workers, and individuals living in geographically remote areas who could not attend classes in classrooms (Simonson and Berg, 2016). Zenović and Bagarić (2014) among distance learners also mention women, who did not have adequate access to educational content at that time. Prior to the development of digital and electronic technologies, the medium that connected students/trainees and teachers/mentors was regular post. As technology developed, there was a change in the media used, post was replaced first with radio and then television.

Nowadays, distance education refers to learning and teaching online, in "virtual classrooms", it is Internet-based instruction, often called e-learning. Considering the technological changes, depending on the time period, it can be concluded that distance education is based on the use of currently available technologies for information exchange (Jukić, 2017). Today, distance education is based on the Internet, and Budić and Hak $(2014$, p. 3) define it with the following elements:

- "temporal and spatial separation of teachers and students during a longer part of the educational process,

- use of the educational medium (usually the Internet) for the purpose of connecting teachers and students and for the purpose of presenting educational content,

- ensuring two-way communication between teachers and students,

- emphasis on controlling the process of acquiring teaching content, primarily by students".

The basic advantages of this form of teaching compared to traditional classroom teaching include: individualized instruction that allows learners to progress at their own pace, learners are in frequent contact with sources of information, which increases their activity, information travels instead of people, thus reducing costs. Although distance education has its advantages, there are certain disadvantages (Bulić, 2018). According to Kalamković et al. (2013), the disadvantages of distance education are: the lack of physical contact between participants in the educational process, all students must have the appropriate technology (computer, the Internet connection), the complexity of the required technology (e.g. videoconferencing). The lack is seen also in the high percentage of dropouts from this form of education due to the lack of student perseverance or ability, while due to the physical isolation a high degree of activity and self-discipline is required (Zenović and Bagarić, 2014). Furthermore, significant are the results of a study by Gökbulut (2020) based on focus group interviews involving 27 distance education students in Turkey. For students, the disadvantages include the lack of student - teacher interaction, the differences in teaching methods (some teachers only read from slides, lessons are not interactive). On the other hand, the advantages include easy access to teaching materials, the possibility of re-watching recorded lectures, and saving time. From the above-mentioned, it can be seen that the success of distance education requires the cooperation and systematic work of all participants in this form of 
teaching (Bulić, 2018). The primary role of learners, as in traditional teaching, is to gain new knowledge that requires motivation, planning, and the ability to analyze and apply the teaching content. The role of the teacher is based on understanding the learners' needs and characteristics in a situation of limited or no face-to-face contact, on adapting the style of teaching and successful functioning in this form of teaching associated with understanding technology. Although it is important to understand technology for quality distance education, Anetta and Shymanski (2008) point out that teachers are too often not trained to effectively use available technologies and therefore do not take advantage of them when designing teaching content.

According to Li et al. (2017), the factors influencing teachers' attitudes to online distance education are motivation and previous experience in this form of teaching. The results of research by Allen et al. (2012) showed that teachers with previous experience in online teaching have more positive attitudes to online teaching compared to teachers without such experience and believe that online teaching can be as effective as face-to-face teaching.

The beginnings of distance education in modern Croatian history date back to 1991, when the Ratna TV škola (War TV School) was started. It was a special educational program broadcast on the Croatian Television launched due to the then war in the Republic of Croatia (hereinafter: $\mathrm{RH}$ ).

The new transition from classroom to distance education in all elementary and secondary schools as well as in higher education began with the Decision of the Government of the Republic of Croatia adopted on 13 March 2020, which occurred due to the pandemic of the new infectious coronavirus COVID-19. The Croatian Ministry of Science and Education (hereinafter: MZO) and Croatian Radiotelevision (hereinafter: HRT) joined forces to organize TV lessons broadcast for students in the lower grades in the form of a program called Škola na trecem (School on the Channel 3), all in line with the current curriculum and syllabus. For students in the upper grades of elementary school, classes were organized on Sports Television in the form of video lectures and online, while for secondary school students on March 23 classes were organized in the same forms on the RTL2 channel (Ministry of Science and Education, 2020). The schedule of classes was published on the websites of Škola za život (School for Life), the Ministry of Science and Education, and the Croatian Academic Research Network (hereinafter: CARNet). Classes for lower grades organized as part of the program called Škola na trećem were broadcast in the morning, lasting one hour. The learning content was covered within 15 minutes per subject. The program was replayed in the afternoon, and students were able to follow the lessons on YouTube. Hearing-impaired students could watch the program on the Facebook page of the Croatian Association of Sign Language Interpreters. School principals connected to "virtual classrooms" using the Loomen system to exchange and monitor information, and to organize "virtual staffrooms". Subject teachers as well as high school teachers organized "virtual classrooms" in one of the systems for communication, learning, and collaboration (Moodle, Yammer, Teams, etc.). Class teachers were advised to stay in 
touch with parents creating virtual groups through communication channels (Viber, WhatsApp, e-mail, Facebook, etc.) as well as to send the parents additional tasks for their children related to the covered teaching content (Ministry of Science and Education, 2020). After watching classes on television in their homes, the students would receive assignments from their teachers, which they would hand in to the teachers in the form of homework assignments. The evaluation was done through already agreed channels. Regarding evaluation and assessment, very demanding processes in distance education, instructions for their implementation in a virtual environment were published. Student activity can be monitored through homework assignments (Bulić and KostovićVranješ, 2019), independent research or collaborative learning, and formative and summative evaluation can be conducted through discussions, tests, didactic games, quizzes, assignments, portfolios, research papers, presentations etc. Evaluation and assessment in class teaching with regard to student age and communication through parents has its own specifics. For class teaching, it was recommended to monitor student activities through the preparation of homework and exercises, and through mind maps, drawings, essays, posters etc. It was also emphasized that students in lower grades should not be examined orally during this form of teaching (Ministry of Science and Education, 2020).

During the pandemic, general teaching conducted by class teachers took place remotely through television, including Science and Society classes, which our research was focused on. Teachers along with their students followed the lessons on television, and after Science and Society classes were broadcast, they sent them appropriate homework assignments. Students of the Faculty of Humanities and Social Sciences in Split attended all classes online and in this research they presented their own views on distance education. In addition to regular online classes, the students had the additional task of watching Science and Society classes on television as part of the program Škola na trećem, all within the framework of the course Methodology of Teaching Science and Society.

The aim of the research was to determine whether teachers and students of Teacher Education have different attitudes to distance education and if they differ in terms of their participation and work during distance education. In accordance with the research objective, the null research hypotheses were formed:

H1 There is no statistically significant difference in the difficulty of transitioning from regular to distance education between teachers and students of Teacher Education.

H2 There is no statistically significant difference in the time spent on weekly preparation for distance education compared to regular teaching preparation between teachers and students of Teacher Education.

H3 There is no statistically significant difference in the education for the application and use of digital tools between teachers and students of Teacher Education. 
H4 There is no statistically significant difference in the perception of the importance of technical support during distance education between teachers and students of Teacher Education.

H5 There is no statistically significant difference in attitudes to televisionbased Science and Society education between teachers and students of Teacher Education.

The first four hypotheses refer to teachers' and students' perception of distance education in general, and the fifth hypothesis refers to television-based Science and Society classes.

\section{METHODOLOGY}

\section{SAMPLE OF RESPONDENTS}

A total of 329 respondents participated in the study. The respondents were class teachers $(\mathrm{N}=267)$ and students $(\mathrm{N}=62)$ of the fourth and fifth year of the Faculty of Humanities and Social Sciences in Split, majoring in Teacher Education. Teachers who participated in the research work in several Croatian counties (Figure 1). Most teachers come from Split-Dalmatia County (28.8\%).

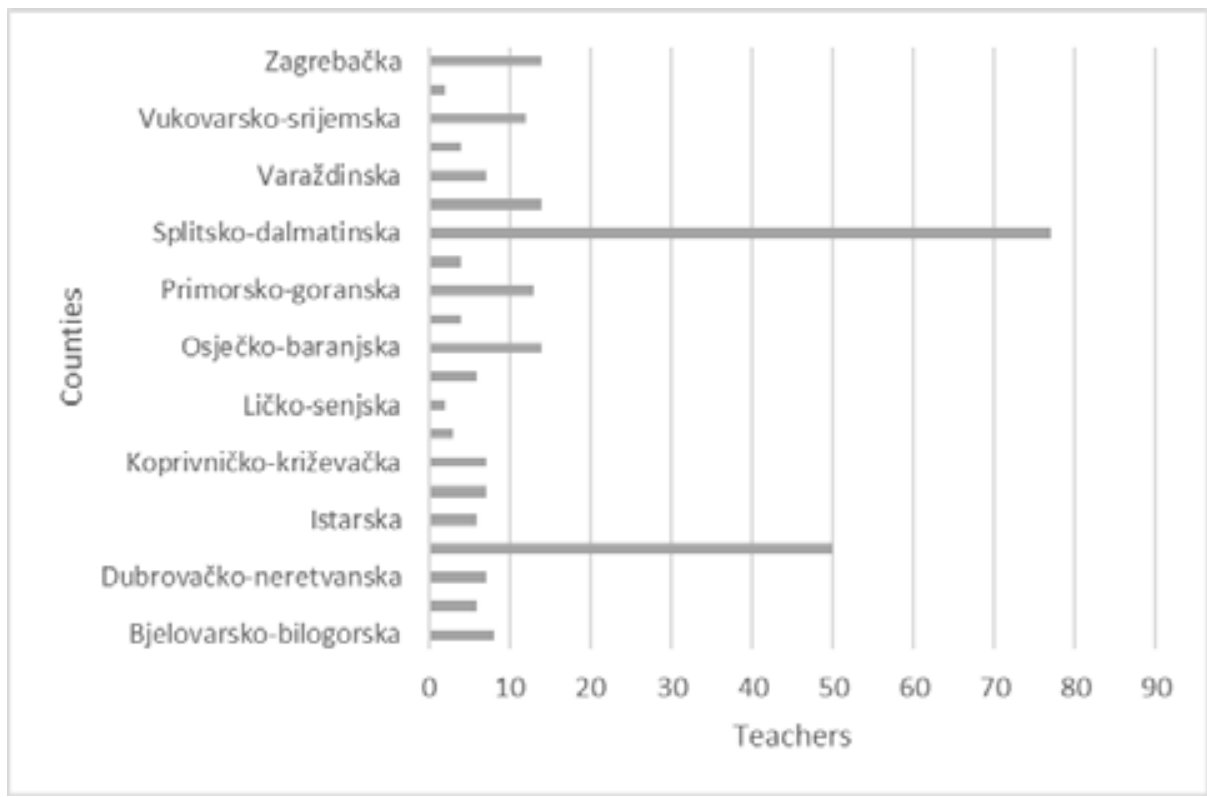

Figure 1. The sample of surveyed teachers with regard to counties

The total number of surveyed teachers included $95.9 \%(\mathrm{~N}=256)$ females and $4.1 \%(\mathrm{~N}=11)$ males. The majority of teachers who participated in the 
survey work in urban schools $(65.9 \%)$ and $34.1 \%$ work in rural schools. In terms of their titles, there are $75.3 \%$ teachers, $12.7 \%$ mentors, and advisors $12 \%$. A total of $15.7 \%(\mathrm{~N}=42)$ of respondents have up to five years of work experience, while $34.8 \%(\mathrm{~N}=93)$ have 6 to 15 years, $26.6 \%(\mathrm{~N}=71)$ have 16 to 25 years, and $22.8 \%$ teachers $(\mathrm{N}=61)$ have 26 or more years of experience. The sample of class teachers consisted of teachers who completed an anonymous online questionnaire. Class teachers teach, in addition to other subjects, Science and Society, therefore all those who chose to complete the questionnaire participated in the research.

As the research examined the attitudes of students as well, 62 students participated in the research. The majority of surveyed students are female students (96.8\%), and male students make up only $3.2 \%$ of the sample. The sample consisted of $41.9 \%(\mathrm{~N}=26)$ of fourth-year students and $58.1 \%(\mathrm{~N}=36)$ of fifthyear students. The sample of student respondents included the fourth- and fifth-year students of Teacher Education of the Faculty of Humanities and Social Sciences in Split since only they got the task to watch TV lessons in Science and Society as part of the program Škola na trećem, within the framework of the course Methodology of Teaching Science and Society.

\section{SAMPLE OF INSTRUMENTS}

For the purposes of the research, two questionnaires were prepared, one for class teachers (A1) and one for fourth- and fifth-year students of the Faculty of Humanities and Social Sciences in Split, majoring in Teacher Education (A2). Both questionnaires in the first part examine the socio-demographic characteristics of the respondents, and the rest of the questionnaire refers to replying to a series of statements and expressing the level of agreement with them.

The first part of the questionnaire for teachers (A1) examined the socio-demographic characteristics of respondents: county in which they work, gender, place of work (village/city), title, work experience, the time needed for the preparation and implementation of distance education, and previous experience in distance education. The second part of the questionnaire consisted of 33 closed-ended items to which teachers responded using the five-point Likert scale (1 - I completely disagree, 2 - I mostly disagree, 3 - I neither agree nor disagree, 4 - I mostly agree, 5 - I completely agree), which examined their attitude or the level of agreement with the mentioned statements. The final four questions were open-ended. Teachers were able to write what they considered to be the advantages and disadvantages of distance education. The final two questions referred to TV-based Science and Society education. The respondents were asked about their opinion on the advantages and disadvantages of the TV classes. 
The questionnaire for students consisted of three parts. The first part included socio-demographic data on respondents: county, gender, year of study. The second part consisted of 26 items / closed-ended statements to which students responded using the five-point Likert scale ( 1 - I completely disagree, 2 - I mostly disagree, 3 - I neither agree nor disagree, 4 - I mostly agree, 5 - I completely agree), which examined their attitude or the level of agreement with the mentioned statements about distance education at the faculty. There were four open-ended questions in the questionnaire: what the student respondents consider to be advantages of distance education, what they consider to be disadvantages of distance education, what they consider to be advantage of TV-based Science and Society education, and what they consider to be the disadvantages. All respondents completed the questionnaire voluntarily and anonymously and were informed about the aim of conducting the survey. Teachers and students completed the questionnaire online. The survey was conducted in May 2020 and lasted for 15 days.

\section{DATA PROCESSING METHODS}

For all data, the parameters of descriptive statistics were calculated: arithmetic mean, standard deviation, median, minimum, maximum, coefficient of variation, coefficient of skewness, and coefficient of flatness. The normality of data was checked by the Kolmogorov-Smirnov test, and it was determined that the results did not deviate significantly from the normal distribution. Using the t-test for independent samples, the statistical significance of differences in the arithmetic means of the respondents' responses was examined, and thus the hypotheses were tested. The results are considered significant if $p<0.05$. All results were calculated using Statistica 13.1 software.

\section{RESULTS AND DISCUSSION}

Questionnaires A1 and A2 were used in the research of the attitudes of class teachers and students of Teacher Education to distance education in which they participated. Table 2 shows the results of descriptive statistics for the identical items of the A1 (for teachers) and A2 (for students) questionnaires.

Table 2 shows that teachers show greater level of agreement with the statement about the difficulty of transitioning from regular to distance education in relation to students, i.e. teachers perceive the transition from regular to distance education more difficult than students. The lowest value or minimum for this variable is 1.00 (I completely disagree), which means that there are teachers and students who do not find the transition to distance education difficult. The highest value or maximum is 5.00 (I completely agree) for both groups of respondents, which indicates that some teachers and students found the transition completely difficult. 
Teachers need more time per week than students to prepare lessons for distance education compared to regular lessons. In this variable as well, the minimum for both groups of respondents is 1.00 and the maximum is 5.00 .

Table 2. The results of descriptive statistics for the items of A1 and A2 questionnaires comparing students and teachers (AM-arithmetic mean; med-median; min-minimum value; max-maximum value; SD-standard deviation; V-coefficient of variability)

\begin{tabular}{|c|c|c|c|c|c|c|c|}
\hline Variables & Respondents & $\mathbf{A M}$ & med & $\min$ & $\max$ & SD & $\mathbf{V}$ \\
\hline \multirow{2}{*}{$\begin{array}{l}\text { I find the transition } \\
\text { from regular to } \\
\text { distance education } \\
\text { difficult. }\end{array}$} & Student & 2.56 & 2.00 & 1.00 & 5.00 & 1.17 & 45.6 \\
\hline & Teacher & 3.31 & 3.00 & 1.00 & 5.00 & 1.30 & 39.3 \\
\hline $\begin{array}{l}\text { Distance education } \\
\text { preparation took me }\end{array}$ & Student & 3.98 & 4.00 & 1.00 & 5.00 & 1.11 & 27.8 \\
\hline $\begin{array}{l}\text { compared to regular } \\
\text { classes. }\end{array}$ & Teacher & 4.22 & 5.00 & 1.00 & 5.00 & 1.15 & 27.2 \\
\hline \multirow{2}{*}{$\begin{array}{l}\text { A good internet } \\
\text { connection is } \\
\text { essential for quality } \\
\text { distance education. }\end{array}$} & Student & 4.77 & 5.00 & 3.00 & 5.00 & 0.49 & 10.3 \\
\hline & Teacher & 4.49 & 5.00 & 1.00 & 5.00 & 0.98 & 21.9 \\
\hline \multirow{2}{*}{$\begin{array}{l}\text { Technical problems } \\
\text { occur during distance } \\
\text { education. }\end{array}$} & Student & 4.18 & 4.00 & 2.00 & 5.00 & 0.95 & 22.7 \\
\hline & Teacher & 3.69 & 4.00 & 1.00 & 5.00 & 1.20 & 32.4 \\
\hline $\begin{array}{l}\text { After introducing } \\
\text { distance education, }\end{array}$ & Student & 4.08 & 4.00 & 1.00 & 5.00 & 0.91 & 22.3 \\
\hline $\begin{array}{l}\text { about the use and } \\
\text { application of } \\
\text { various digital tools. }\end{array}$ & Teacher & 4.32 & 5.00 & 1.00 & 5.00 & 1.09 & 25.1 \\
\hline \multirow{2}{*}{$\begin{array}{l}\text { TV-based Science } \\
\text { and Society } \\
\text { education is } \\
\text { excellent. }\end{array}$} & Student & 2.97 & 3.00 & 1.00 & 4.00 & 0.89 & 29.9 \\
\hline & Teacher & 2.64 & 3.00 & 1.00 & 5.00 & 1.12 & 42.5 \\
\hline
\end{tabular}

Teachers additionally educated themselves to be able to use various digital tools and compared to students they show greater agreement with the statement about self-education regarding the use and application of various digital tools 
after introducing distance education. Students find a good internet connection more important for the quality of distance education than teachers. They are also more likely to notice the emergence of technical problems than teachers. As for TV classes organized by the Ministry of Science and Education on public television, both groups of respondents express a medium agreement with the statement that such form of education is excellent.

The obtained research results were verified by the Kolmogorov-Smirnov test to determine the normality of the data. As the normal data distribution was shown, t-test for independent samples was used in the further analysis. Table 3 shows the results of the t-test for independent samples, which was done with the aim of identifying the significance of differences in the responses of surveyed teachers and students. The difference is considered statistically significant if $\mathrm{p}<0.05$.

Table 3. The t-test results related to the comparison of identical variables for teachers and students (M-arithmetic mean; $t$-value of t-test; df-degrees of freedom; p-level of significance)

\begin{tabular}{lccccc}
\hline Variables & $\begin{array}{c}\text { M } \\
\text { (teachers) }\end{array}$ & $\begin{array}{c}\text { M } \\
\text { (students) }\end{array}$ & t & df & p \\
\hline $\begin{array}{l}\text { I find the transition } \\
\text { from regular to distance } \\
\text { education difficult. }\end{array}$ & 3.31 & 2.56 & 4.14 & 327 & $<\mathbf{0 . 0 1}$ \\
$\begin{array}{l}\text { Distance education } \\
\text { preparation took me more } \\
\text { time weekly compared to } \\
\text { regular classes. }\end{array}$ & 4.22 & 3.98 & 1.49 & 327 & 0.14 \\
$\begin{array}{l}\text { A good internet connection } \\
\text { is essential for quality } \\
\text { distance education. }\end{array}$ & 4.49 & 4.77 & -2.18 & 327 & $\mathbf{0 . 0 3}$ \\
$\begin{array}{l}\text { Technical problems occur } \\
\text { during distance education. }\end{array}$ & 3.69 & 4.18 & -2.99 & 327 & $<\mathbf{0 . 0 1}$ \\
$\begin{array}{l}\text { After introducing distance } \\
\text { education, I independently } \\
\text { educated myself about } \\
\text { the use and application of } \\
\text { various digital tools. }\end{array}$ & 4.32 & 4.08 & 1.62 & 327 & 0.11 \\
$\begin{array}{l}\text { TV-based Science and } \\
\begin{array}{l}\text { Society education is } \\
\text { excellent. }\end{array}\end{array}$ & 2.64 & & & & \\
\hline
\end{tabular}

Table 3 shows there is a statistically significant difference in the responses of teachers and students about the difficulty of transitioning from regular 
to distance education $(\mathrm{p}=0.00)$, which indicates that for teachers the switch from regular to distance education was statistically significantly more difficult. The result of the t-test does not confirm the hypothesis H1. The reasons for such perception of the difficulty of transitioning from regular to online teaching can certainly be in the level of development of teachers' digital competence. As already mentioned, $22.8 \%$ of surveyed teachers have over 26 years of work experience and belong to a group that did not have a formal education in Informatics during school and university education. They acquired all the necessary skills and knowledge in additional courses during their years of service. It was noticed that there is no statistically significant difference with regard to work experience and the type of school in which respondents work, which correlates with the results of the research by Bulić and Novoselić (2016). As the conducted studies (Bulić and Novoselić, 2016; Kostović-Vranješ, 2011; Kostović-Vranješ et al., 2015) indicated the reluctance of Science and Society teachers to apply ICT in teaching and the need to enhance their ICT competences, this could present one of the reasons why teachers find it more difficult to switch from regular to online teaching. It can be assumed that the poor level of integration of computer content in the teaching process is correlated with the lack of teachers' digital competences (Krumsvik, 2014). Lukša and Vuk (2014) came to the same conclusion. Kostović-Vranješ et al. (2015) point to the lack of computer skills of Biology teachers leading to a low level of ICT use in teaching, and during online teaching conducted in schools in 2020 the computer was their primary tool for communicating with students, sharing and reviewing teaching content. On the other hand, the transition to online teaching is not as difficult for students as for teachers because ICT is close to them, and during formal education all students had the subject of Informatics. Some students who participated in the research in addition to class teaching study the application of ICT in early learning and teaching (Module 2).

For the variable on the required weekly time needed for preparation for distance education compared to regular classes, no statistically significant difference was found $(\mathrm{p}=0.14)$, which indicates that hypothesis $\mathbf{H} \mathbf{2}$ was confirmed. It is assumed that teachers responsibly approached distance education and independently prepared the necessary content for the work or used ready-made materials from publishing houses or materials prepared by the Ministry. Those who used to prepare well and independently for regular classes continued to do so during distance education. During regular classes, students independently prepared for seminars or exercises according to the established schedule, and such a pattern of behavior continued during distance education, therefore there is no difference in the weekly time spent on preparation.

Hypothesis $\mathbf{H 3}$ was confirmed, no statistically significant difference was identified in the responses of teachers and students on self-education on the use and application of different digital tools $(\mathrm{p}=0.11)$. Both groups educated 
themselves because they had to use new digital tools and platforms that they have not used before. During distance education, teachers used various systems such as Edmodo, Yammer, and other tools for communication, information exchange, and learning. Online classes were also followed on the website of Škola za život (https://skolazazivot.hr/video-lekcije/), the YouTube channel and the television programs HRT3 and SPTV. The students of the Faculty of Humanities and Social Sciences attended online classes via Google Hangouts Meet. The transition to a new way of working in the new digital environment implied rapid self-education about the new tools that were to be used by both groups of respondents, therefore there is no statistically significant difference between them.

The results of the t-test do not confirm the hypothesis H4. Namely, it was shown that compared to teachers, students consider statistically significantly more important the existence of a good internet connection for quality distance education. Students point to technical problems during distance education more than teachers. Certainly, the Internet connection is an essential factor in distance education. However, as most class teachers did not have classes in real time with their learners, but the learners followed the classes on HRT3 and teachers sent them presentations, worksheets and various didactic materials for work, they could do their job at any time of the day. In contrast, at the faculty, the instruction took place online in real time and students find the Internet connection very important for quality class participation.

Hypothesis $\mathbf{H 5}$ was not confirmed because the t-test revealed a statistically significant difference $(p=0.03)$ between the answers of teachers and students for the variable related to TV-based Science and Society education, i.e. it was shown that students express more positive attitudes to the TV classes. A possible reason for such a perception is that teachers, as experts who know the subject curriculum well, can look at the content broadcast on television in more detail and objectively and see the discrepancies with the Yearly Curriculum. During distance education, it could be noticed that some classes last only two or three minutes, and the covered topic cannot be connected with any teaching unit. Moreover, teachers noticed certain material errors that occurred during TV-based education, e.g., during a Science and Society class the teacher was holding a snail's shell (kućica) in her hand and telling the children that it is a shell (školjka). Teachers also notice other methodological errors such as a poor board plan, not deleting the board plan after the lesson, improper demonstrations or conducting experiments. Students notice such mistakes not that easily because they do not yet have sufficient methodological knowledge. The PowerPoint presentations that the teachers presented during Science and Society classes were not uniform. The students' attention was distracted by the logos at the bottom of the PPT presentations, and the logo in the upper right corner, the slides were sometimes not methodically well-formatted (the font 
was sometimes too large, the whole text appeared all at once, not gradually, photos and images were sometimes of questionable quality, the camera did not follow exactly what the teacher was talking about etc.). These are precisely the reasons why teachers find the quality of TV-based Science and Society education poorer than students.

It is worrying that almost $40 \%$ of teachers notice that Science and Society homework assignments are done not by learners but someone else during distance education (Figure 2).

Parents write homework instead of my learners during distance educatic

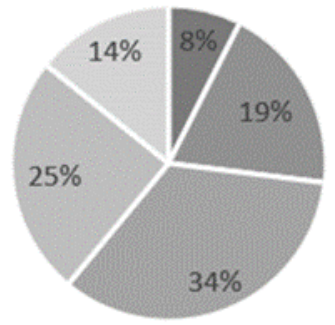

- I completely disagree

- I neither agree nor disagree

I completely agree

Figure 2. Teachers' responses to the item: "Parents write homework instead of my learners during distance education" shown in percentages

This is by no means justified or good because homework should enable learners to process information obtained during classes (Painter, 2003) and help them achieve the desired educational outcomes of any subject, including Science and Society. If the child did not write homework, the question is if she/he has achieved the required learning outcome. Parents, working instead of their own children, did them no favors but deprived them of thinking about the task and looking for a solution and reasoning. The research by Bulić and Kostović-Vranješ (2019) on learners' self-responsibility in writing homework during e-learning (fully online teaching) shows that working in a digital environment was a motivating factor for leaners and they did write their homework. Moreover, the responsibility in writing homework is higher among younger students compared to seventh- and eighth-grade students. Through careful qualitative analysis, the authors found that even less active students regularly performed their homework assignments during online teaching. 
Since both groups of respondents had open-ended questions at the end of the questionnaire, a qualitative analysis of their answers was made. As an advantage of distance education, $56 \%$ of students pointed out time flexibility because distance education allows them to do tasks better and to have more time to do them: "Since I have more time, I can do tasks better", "More time to complete tasks". Furthermore, respondents point out that in distance education they can better organize their learning time: "The advantage of distance education is certainly that students have more time to organize their obligations", "Students organize their time as they wish and do tasks when they are most productive", "Organizing learning time independently". Students also point out that they do not waste time on travelling: "Saving time because we don't have to travel to our faculty (I need about half an hour by car to go there and half an hour to go back home)", "The advantage is that no time is wasted on transportation", "One of the big savings is on the time needed to go to and from the faculty". In addition to time flexibility, students also mention spatial flexibility as an advantage $(42 \%)$ emphasizing the possibility of class participation from anywhere (from different locations, primarily in the comfort of their own home): "Comfort of listening to lectures from home", "We can follow the lessons from wherever we want (in the environment that suits us best)". These results correlate with the results of the research by Jukić (2017) conducted on a sample of 1318 students from Croatian universities in which the surveyed students recognized the flexibility in terms of places of learning as an advantage of online learning. Students find online learning affordable because it goes beyond the physical distance between professor and student and gives students access to teaching materials at any time.

As a lack of distance education, $50 \%$ of students point out the lack of physical (face to face) contact and the lack of interaction and social contact with professors and other students. Students find that communication during online classes is worse than during regular classes. This result correlates with a study by McBrien et al. (2009) which shows that for the surveyed students the element of personal contact with professors and other students, which misses in online teaching, reduces their sense of belonging as well as a sense of class participation. Analyzing the attitudes of doctoral students at the Faculty of Kinesiology in Split, Gabrilo and Rodek (2009) found out that students consider communication in distance education poorer than in regular teaching. The surveyed students point out that due to the lack of physical contact in distance education, it is difficult for teachers to monitor student activity and participation in classes: "Professors cannot keep track of how many people participate in the lecture", "We can connect and not listen to the lectures", "We don't have to participate in classes", "Many do not participate in distance education at all". Furthermore, students (42\%) notice they have more tasks compared to teaching at the faculty, which they see as a lack of distance education: "Disadvantages 
are more tasks than in classic teaching", "The disadvantage of distance education is that professors give us $70 \%$ more assignments than before", "Professors think we have more time, and in fact we have the same amount of time as before because we have the same lectures as before. The difference is that we have more tasks". According to the study by Smidt et al. (2014) on students' attitudes to distance education, students believe that this form of teaching has a large workload and requires a greater level of student autonomy in learning. In contrast to face-to-face teaching where students would be given tasks only on the day when the class was held, in distance education students are given assignments throughout the week regardless of the schedule.

Among disadvantages, students (13\%) further mention the technical difficulties they encountered during distance education, which most often occur due to problems with the Internet connection. Certainly the lack of distance education is the time spent sitting in front of the computer: "More time spent in front of the laptop, which affects our health", "In front of the screen we literally spend days from morning to night and from Monday to Sunday even".

The disadvantage of TV-based Science and Society education, according to $36 \%$ of surveyed students (who followed the classes as part of the course Methodology of Teaching Science and Society), is short class time, whereby some classes lasted less than five minutes. Students believe that due to the above, there is a lack of time to explain important concepts and that not all the necessary educational outcomes can be achieved in a short time. As a lack of distance education organized on television, $31 \%$ of respondents point out the impossibility of achieving interaction and communication at the levels teacher - student and student - student. It is therefore not possible to get feedback from learners or monitor their understanding of the content. As an advantage of TV-based Science and Society education, the students stated that learners got the opportunity to continue with learning in this way and to at least follow the required teaching contents.

Teachers $(29 \%)$ see digitalization as an advantage of distance education because this form of education has influenced the development of their and students' digital competences and computer literacy: "Enhancing computer literacy", "Better computer literacy", "More active use of ICT", "Personal education and use of digital technology", "Digital literacy of students". Teachers point out that online teaching helped them discover and start using various digital tools, materials and content: "I discovered new tools and applications for work", "The situation has led to the possibility of using numerous programs that have so far been inaccessible to most teachers due to their high cost, so that now teaching is more interesting", "The fact that people create and share so much material that we will be able to use in the future". This result correlates with the results of research by Tomaš and Mladenovski (2016) which shows that teachers have positive attitudes to the application of ICT in teaching, that they 
are willing and motivated to change the way of teaching and use ICT in their classes. Moreover, teachers believe that the inclusion of ICT makes classes more creative and improves their quality.

Time flexibility, as an advantage, is recognized by $28 \%$ of teachers: "Learners have the opportunity to organize their time and schedule their work properly", "It is much more flexible than classic teaching. In the sense that the learner does not necessarily have to sit from 8 am to 2 pm", "The time for solving tasks is not limited, which suits many students", "The child has the opportunity to do tasks in her/his own rhythm, she/he can repeat instructions several times", "Learners have more time for creative tasks, so they dedicate themselves with pleasure, invest more effort and time, and amazing works are created".

As a lack of distance education, $62 \%$ of teachers pointed out the lack of direct contact, socialization and interaction with learners: "Lack of direct contact and immediate feedback", "No every day's "living" words and interaction with learners", "Lack of direct communication with learners, everything takes place with the help of parents since I teach first graders". Respondents also point out that teaching and atmosphere in the classroom as irreplaceable: "Human contact, social interaction, direct transfer of knowledge from person to person is irreplaceable". "Interaction through the screen is insufficient because children lack live communication, socializing and interaction with peers, but also with teachers", "Lack of live contact with children; the living word, however, is what makes our work, and no technique can replace it. This is all just an illusion of teaching; there is no teacher, classroom, blackboard and chalk".

A total of $23 \%$ of teachers point out the difficulties in evaluation and assessment as a lack of TV-based Science and Society education. Although the learners followed the lessons on television, they were regularly given homework assignments to be handed in to their teachers for review using various tools. In open-ended answers, teachers question the credibility of the learners' work: "Objectivity of learners' work / evaluation, biased and unrealistic feedback from learners", "The disadvantage of distance education is that most of the tasks can be done by someone else instead of the learners", "The unreliability of the results, I don't know whether the learner copied or worked independently", "A constant feeling that I do not have all aspects of teaching and evaluation under control", "They haven't learned anything, they copy, parents write their assignments, we see that but we have no evidence...The worst students now turn out with the best homework". The surveyed teachers also see a disadvantage in the excessive involvement of parents and solving tasks instead of the children: "Some parents do homework. They even write in their own handwriting. Despite the warnings, this does not stop. These are simple tasks from the workbook that we usually do at school. Not to mention drawing instead of children. I just don't know how I'm going to grade certain children", "Some parents do 
homework for their children. It is impossible to objectively and realistically assess children's knowledge", "Parents write most of the homework", "Results are not realistic because parents are too much (and unnecessarily) engaged in doing their children's homework", "Parents work instead of our learners, the assignments do not reflect the knowledge and I do not get a realistic picture of how much learning content has been acquired". Similarly to students, teachers see an advantage of TV-based Science and Society education in the fact that this form of education is more or less successfully organized and that children have a medium through which they can follow the required teaching contents.

\section{CONCLUSION}

In the challenging pandemic time, the Republic of Croatia managed to change its educational system very quickly. Generally speaking, it was a pretty demanding job that was mostly done successfully. An observation of distance education, which was organized in a very short time and included a complete educational vertical in all educational cycles, shows a need for continuous improvement and expansion of teachers' competence profile as well as for changes in the approach to students' (future teachers') acquiring competences. This experience of distance education should become an integral part of the Methodology of Teaching Science and Society but also other teaching methodologies, enabling the students to finish their studies with a quality competence profile, which is a prerequisite for quality classroom work. In extraordinary circumstances, distance education has proven to be extremely important, and television-based education certainly made it easier for learners to transition from regular to distance education. Extraordinary circumstances such as the current pandemic clearly show how necessary it is to have ready-made, carefully designed didactic-methodological materials from all subjects, including Science and Society.

The research has shown that teachers perceive the transition from regular to distance education as statistically significantly more difficult than students, and both groups of the respondents spend the same amount of time preparing for online classes as they did before for regular classes. Teachers and students educated themselves when they quickly had to start using new tools that they had not used before. Students, in contrast to teachers, find statistically significantly more important the existence of a good internet connection. Although the surveyed teachers and students recognized the advantages of distance education such as temporal or spatial flexibility, they still pointed out its disadvantages, the biggest of which is the lack of direct contact. In order to bridge the gap of physical separation and avoid the feeling of isolation, it is certainly necessary to make contact with learners as often as possible in real time, and this could be achieved by organizing meetings through video communication tools. Distance 
education requires greater autonomy, independence and work of learners, therefore teachers should regulate the amount of homework assignments. Attitudes of students and teachers to television-based education also differ because students express more positive attitudes to this form of education.

It can be said that the challenge of distance education in the time of the pandemic has been successfully met thanks to the dedicated joint work of teachers and their learners. Even after the current health crisis, changes in the educational system of the Republic of Croatia can be realized in the long run based on this experience of distance education.

\section{REFERENCES}

Allen, E.I, Seaman, J., Lederman, D., \& Jaschik, S. (2012). Conflicted: Faculty and Online Education. Babson Survey Research Group and Quahog Research Group, LLC. https://files.eric.ed.gov/fulltext/ED535214.pdf.

Allen, E.I., \& Seaman, J. (2013). Changing Course: Ten Years of Tracking Online Education in the United States. Babson Survey Research Group and Quahog Research Group, LLC.

Annetta, L., \& Shymansky, A.J. (2008). A Comparison of Rural Elementary School Teacher Attitudes Toward Three Modes of Distance Education for Science Professional Development. Journal of Science Teacher Education, 19(3), 255267. https://doi.org/10.1007/s10972-008-9089-4

Boras, M. (2009). Suvremeni pristupi nastavi prirode i društva. Život i škola: časopis za teoriju i praksu odgoja i obrazovanja, 55(21), 40-49. https://hrcak.srce.hr/37079

Budić, H., \& Hak, M. (2014). Primjena suvremene obrazovne tehnologije u nastavi. International conference „Vallis aurea“. (pp. 65-73). Repository of Polytechnic in Pozega. https://urn.nsk.hr/urn:nbn:hr:112:363339

Bulić, M., \& Novoselić, D. (2016). Kompetencije učitelja biologije za izradu računalnih sadržaja i uporabu informacijsko-komunikacijskih tehnologija. Magistra Iadertina, 11(1), 89-104. https://hrcak.srce.hr/177643

Bulić, M., Jelaska I., \& Mandić Jelaska P. (2017). Utjecaj e-učenja na usvojenost ishoda učenja u nastavi Prirode i Biologije. Croatian Journal of Education, 19(2), 447477. https://doi.org/10.15516/cje.v19i2.2230

Bulić, M. (2018). Sustavi e-učenja u promicanju obrazovanja za zdrav i održiv život. [doctoral dissertation, University of Split]. Faculty of Science in Split Repository. https://dr.nsk.hr/islandora/object/pmfst\%3A541/datastream/PDF/view

Bulić, M., \& Kostović-Vranješ, V. (2019). Utjecaj e-učenja na samoodgovornost učenika pri izvršavanju domaćih zadaća. Školski vjesnik, 68(1), 112-126. https://hrcak. srce.hr/230624

CARNet (2020). Europski okvir digitalnih kompetencija za obrazovatelje (DigCompEdu). Hrvatska akademska i istraživačka mreža. https://www.e-skole. hr/wp-content/uploads/2020/04/CARNET_digitalne_kompetencije_2020.pdf 
Ćukušić, M., \& Jadrić, M. (2012). e-učenje: koncept i primjena. Školska knjiga.

Gabrilo, G., \& Rodek, J. (2009). Učenje putem interneta - mišljenja i stavovi studenata. Školski vjesnik, 58(3), 281-299. https://hrcak.srce.hr/82600

Gökbulut, B. (2020). Distance Education Students' Opinions on Distance Education. In M. Durnali, \& I. Limon (Eds.), Enriching Teaching and Learning Environments With Contemporary Technologies (pp. 138-152). IGI Global.

Hutinski, Ž., \& Aurer, B. (2009). Informacijska i komunikacijska tehnologija u obrazovanju: stanje i perspektive. Informatologia, 42(4), 265-272. https://hrcak.srce. $\mathrm{hr} / 42347$

Jukić, D. (2017). Tehnička pripremljenost i motiviranost studenata hrvatskih sveučilišta za online oblik nastave. Život i škola, 63(1), 93-102. https://hrcak.srce.hr/193882

Kalamković, S., Halaši, T., \& Kalamković, M. (2013). Učenje na daljinu primijenjeno u nastavi osnovne škole. Croatian Journal of Education, 15(Sp.Ed.3), 251-269. https:/hrcak.srce.hr/111354

Kostović-Vranješ, V. (2011). Information-communication technologies in biology teaching: present states and possibilities. In J. Milat (Ed.), Digital technologies and new forms of learning (pp. 181-189). Faculty of philosophy University of Split, Faculty of education University of Chieti-Pescara.

Kostović-Vranješ, V. (2015). Metodika nastave predmeta prirodoslovnog područja. Školska knjiga.

Kostović-Vranješ V., Bulić, M., \& Novoselić, D. (2016). Kompetencije učitelja biologije za primjenu informacijsko-komunikacijskih tehnologija u nastavnom procesu. Zbornik radova Filozofskog fakulteta u Splitu, (6-7), 15-26. https://hrcak.srce. $\mathrm{hr} / 154574$

Krumsvik, R. J. (2014). Teacher educators' digital competence. Scandinavian Journal of Educational Research, 58(3), 269-280. https://doi.org/10.1080/00313831.2012 .726273

Li, R., Bunk, J., \& Smidt, E. (2017). Understanding Faculty and Student Attitudes about Distance Education: The Importance of Excitement and Fear. In M. Northcote, K.P. Gosselin (Eds.), Handbook of Research on Humanizing the Distance Learning Experience (pp. 410-435). IGI Global.

McBrien, J.L., Jones, P., \& Cheng, R. (2009). Virtual Spaces: Employing a Synchronous Online Classroom to Facilitate Student Engagement in Online Learning. The International Review of Research in Open and Distributed Learning, 10(3), 1-17. https://files.eric.ed.gov/fulltext/EJ847763.pdf

Ministarstvo znanosti, obrazovanja i športa (2011). Nacionalni okvirni kurikulum za predškolski odgoj, opće obvezno i srednjoškolsko obrazovanje. Republika Hrvatska, Ministarstvo znanosti, obrazovanja i športa. http://mzos.hr/datoteke/ Nacionalni_okvirni_kurikulum.pdf

Ministarstvo znanosti i obrazovanja (2020). Dodatne upute vezano uz obustavu nastave na visokim učilištima. Republika Hrvatska, Ministarstvo znanosti i obrazovanja. https://mzo.gov.hr/UserDocsImages/dokumenti/Vijesti/2020/Dodatne\%20 
upute $\% 20$ vezano $\% 20$ uz $\% 20$ obustavu $\% 20$ nastave $\% 20$ na $\% 20$ visokim $\% 20$ ucilistima\%20-\%2013.\%203.\%202020..pdf

Ministarstvo znanosti i obrazovanja (2020). Uputa svim osnovnim i srednjim školama vezano uz nastavak organizacije nastave na daljinu. Republika Hrvatska, Ministarstvo znanosti i obrazovanja. https://mzo.gov.hr/vijesti/uputa-svim-osnovnim-i-srednjim-skolama-vezano-uz-nastavak-organizacije-nastave-na-dalji$\mathrm{nu} / 3592$

Ministarstvo znanosti i obrazovanja (2020). Upute za vrednovanje i ocjenjivanje tijekom nastavena daljinu. Republika Hrvatska, Ministarstvo znanosti i obrazovanja. https:// mzo.gov.hr/UserDocsImages/dokumenti/Obrazovanje/Upute-za-vrednovanje/ Upute\%20za\%20vrednovanje\%20i\%20ocjenjivanje\%20tijekom\%20nastave $\% 20$ na\%20daljinu.pdf?fbclid=IwAR3hTiwCR87KUwysOJ0yvhxHrI42u7oTsh7ReG2cza_pVp53tZJR14vd4b0

Nadrljanski, Đ. (2006). Informatička pismenost i informatizacija obrazovanja. Informatologia, 39(4), 262-266. https://hrcak.srce.hr/9254

Painter, L., \& Maley, A. (2003). Homework. Kogan Page Publishers.

Pejić Papak, P., \& Grubišić Krmpotić, H. (2016). Poučavanje primjenom suvremene tehnologije u obrazovanju. Život i škola, 62(3), 153-162. https://hrcak.srce. $\mathrm{hr} / 176919$

Simonson, M., \& Berg, G.A. (2016). Distance learning. Encyclopædia Britannica, inc. https://www.britannica.com/topic/distance-learning.

Smidt, E., Bunk, J., McGrory, B., Li, R., \& Gatenby T. (2014). Student Attitudes about Distance Education: Focusing on Context and Effective Practices. The IAFOR Journal of education, 2(1), 40-64. https://files.eric.ed.gov/fulltext/EJ1080350.pdf.

Tinio, V.L. (2003). ICT in Education. E-ASEAN Task Force.

Tomaš, S., \& Mladenovski, A. (2016). The implementation of information and communication technologies in education. In R. Jukić, K. Bogatić, S. Gazibara, S. Pejaković, S. Simel \& A. Nagy Varga (Eds.), Zbornik znanstvenih radova s Međunarodne znanstvene konferencije Globalne i lokalne perspektive pedagogije (pp. 291-300). Filozofski fakultet Osijek.

Zenović, I., \& Bagarić, I. (2014). Trendovi u otvorenom učenju na daljinu u svetu i kod nas. Sinteza, 379-384. http://portal.sinteza.singidunum.ac.rs/Media/files/2014/379-384.pdf. 